\title{
Relationship Between Alcohol Type and Posterior Reversible Encephalopathy Syndrome: A Case Report
}

\section{Alkol Tipi ve Posterior Reverzibl Ensefalopati Sendromu Arasındaki İlişki: Olgu Sunumu}

\author{
(1) Yağmur İnalkaç Gemici1, (1) Canan Çelebi2 \\ ${ }^{1}$ Gonen State Hospital, Clinic of Neurology, Balikesir, Turkey \\ 2Torbali State Hospital, Clinic of Neurology, Izmir, Turkey
}

\begin{abstract}
Posterior reversible encephalopathy syndrome (PRES) is a clinical-radiologic syndrome characterized by headaches, altered mental status, seizures, visual symptoms, hallucinations, focal neurologic signs, and vasogenic edema in the posterior cerebral circulation territory, which develops within hours to days. The common etiology of PRES includes cytotoxic medication, preeclampsia, eclampsia, sepsis, renal disease or autoimmune disorders. However, alcohol withdrawal can be counted as one of the rarest causes of PRES. The relationship with PRES and the duration of alcohol use or type of alcohol is unknown. Herein, we report a 39-yearold male patient who was diagnosed as having PRES associated with the sudden withdrawal of alcohol (under-the-counter ethanol) and had a much shorter period of alcohol abuse than those reported in the literature.
\end{abstract}

Keywords: PRES, alcohol withdrawal, seizure

\section{$\ddot{\mathbf{O} z}$}

Posterior reversibl ensefalopati sendromu (PRES), saatlerle günler içinde gelişen posterior serebral dolaşım bölgesinde baş ağriları, değişen zihinsel durum, nöbetler, görsel semptomlar, halüsinasyonlar, fokal nörolojik bulgular ve vazojenik ödem ile karakterize klinik-radyolojik bir sendromdur. PRES'nin ortak etiyolojisi sitotoksik ilaç, preeklampsi, eklampsi, sepsis, böbrek hastalığ1 veya otoimmün bozuklukları içerir. Ancak alkol yoksunluğu PRES’nin en nadir nedenlerinden biri olarak sayılabilir. PRES ile alkol kullanım süresi veya alkol türü arasındaki ilişki bilinmemektedir. Bu olguda, tezgah altı etanol ile yapılan alkolün ani kesilmesi ile ilişkili PRES tanısı konmuş ve literatürde bildirilenden çok daha kısa alkol kötüye kullanımı süresi olan 39 yaşında bir erkek hasta sunulmaktadır.

Anahtar Kelimeler: PRES, alkol yoksunluğu, nöbet

\section{Introduction}

Posterior reversible encephalopathy syndrome (PRES) was first described by Hinchey et al. (1) in 1996. PRES is characterized by clinical symptoms and radiologic findings including hypertension, headaches, seizures, visual symptoms, hallucinations, altered mental status and cortical-juxtacortical fluid-attenuated inversion recovery (FLAIR) hyperintensity, predominantly in the parietooccipital cortex (2). PRES often occurs in the setting of preeclampsia, autoimmune disorders, toxic agents and metabolic disorders (3). In this report, we present a case of PRES associated with the sudden withdrawal of alcohol caused by under-thecounter ethanol. The striking feature of our patient was that the history of alcohol abuse was much shorter than those reported in the literature. Therefore, the case is presented with the approval of the patient.

\section{Case Report}

A 39-year-old male patient presented to our neurology outpatient clinic with a generalized tonic-clonic seizure. The patient's history revealed that the patient had hallucinations one day prior to presentation. The seizures experienced by the patient were accompanied by unconsciousness, whole-body convulsions, and involuntary upward deviation of the eyes and were clonic type and lasted for 20-30 second. The patient stated that he began consuming alcohol 14 months earlier and had not consumed alcohol for the last four days. It was also revealed that

Address for Correspondence/Yazışma Adresi: Yağmur İnalkaç Gemici MD, Gonen State Hospital, Clinic of Neurology, Balikesir, Turkey Phone: +90 5432517710 E-mail: yagmurgemici@outlook.com ORCID: orcid.org/0000-0001-7888-5396

Received/Geliş Tarihi: 20.04.2020 Accepted/Kabul Tarihi: 07.07.2020

${ }^{\circ}$ Copyright 2021 by Turkish Neurological Society

Turkish Journal of Neurology published by Galenos Publishing House. 
the patient produced under-the-counter alcohol due to economic constraints by mixing one liter of ethanol with 1.5 liter of tap water, three lumps of sugar, and a small amount of aniseed oil to obtain a total of 2.5 liter of alcohol, which he consumed within a period of three days. On admission, the patient had an arterial blood pressure of $150 / 100 \mathrm{~mm}$ hemoglobin and was hospitalized in our neurology inpatient clinic due to a prediagnosis of PRES, which was established based on the triad of hypertension, seizure, and visual hallucination. The patient partially sustained nutrition during the 4-day alcohol-free period. The patient was initiated on a psychiatric therapy for the treatment of alcohol abuse including lorazepam $1 \mathrm{mg}$, folic acid, and haloperidol drops in the presence of hallucinations. Additionally, an antiepileptic therapy with levetiracetam $1000 \mathrm{mg} /$ day peroral was also initiated. A cranial magnetic resonance imaging (MRI) scan was performed on the first and fifth days of hospitalization. The first-day MRI scan revealed bilateral occipital hyperintensities on FLAIR sequences (Figure 1A, 2A), which resolved significantly on the fifth-day scan (Figure 1B, 2B). Electroencephalography showed no significant abnormality. Based on these signs and symptoms, the patient was diagnosed as having PRES. All the symptoms resolved after treatment and then the patient was transferred to the psychiatry department for the treatment of alcohol abuse.

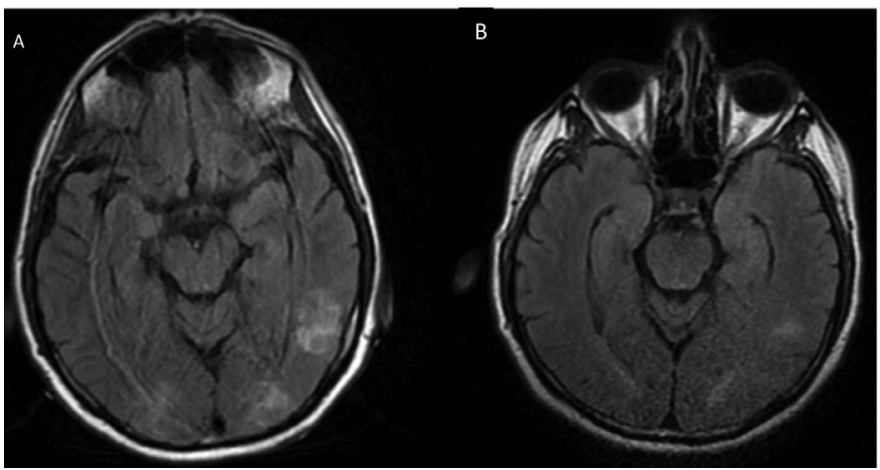

Figure 1. A) First-day cranial magnetic resonance imaging (MRI) showing bilateral occipital hyperintense nodular lesions on FLAIR sequences, predominantly on the left side. B) Fifth-day cranial MRI showing a significant reduction in lesions

FLAIR: Fluid-attenuated inversion recovery

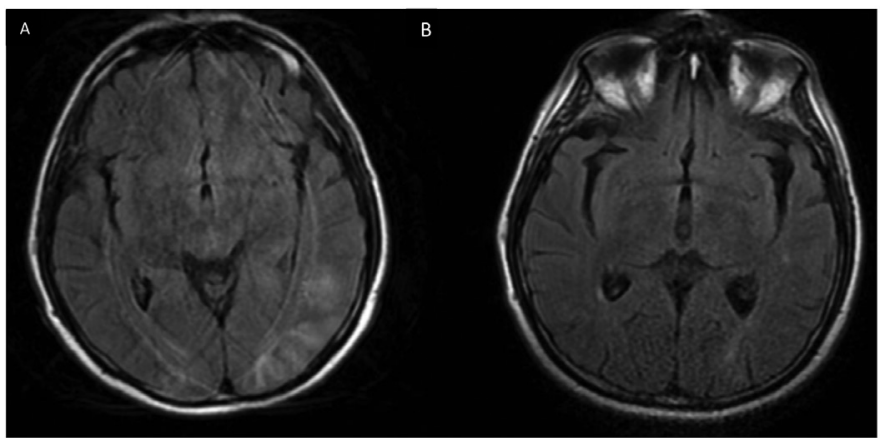

Figure 2. A) First-day cranial magnetic resonance imaging (MRI) showing bilateral temporo-occipital hyperintense nodular lesions on FLAIR sequences, predominantly on the left side. B) Fifth-day cranial MRI showing a significant reduction in lesions

FLAIR: Fluid-attenuated inversion recovery
To our knowledge, there have been few cases of PRES secondary to alcohol withdrawal reported in the literature, in whom the type of alcohol was unknown and both patients had a long history of alcohol abuse ( $>35$ years). In the case presented in this report, unlike the previous cases, the type of alcohol consumed by the patient was known and the patient had a shorter history of alcohol abuse.

\section{Discussion}

Patients with PRES typically present with vasogenic edema involving the posterior cerebral artery. Neurotoxicity is the primary etiology of PRES, which has a wide clinical spectrum involving headaches and focal neurologic deficits. Although at first, hypertension was the hallmark of PRES, normotensive patients are also currently accepted as having PRES. The syndrome mostly occurs in the setting of preeclampsia-eclampsia, sudden hypertension, renal failure, autoimmune disorders, infections, sepsis, transplantation, and chemotherapy. The pathophysiologic theory of PRES is incomplete because it does not explain how severe hypertension results in vasogenic edema and why PRES can also be seen in normotensive patients. There is another theory that the vasogenic edema results from hypoperfusion and that cerebral ischemia occurs secondary to vasoconstriction. Finally, in the immune theory, PRES may result from immunodeficiency (4).

The radiological sign of PRES on MRI is the presence of reversible hyperintense T2-FLAIR lesions in the posterior cerebral region (5). In the case presented, the diagnosis of PRES was confirmed by the significant reduction of hyperintense lesions on the fifth-day MRI.

Individuals producing under-the-counter alcohol sometimes use synthetic ethanol either unknowingly or due to economic constraints. Alcohol abuse can lead to acute and chronic toxicity, and its sudden withdrawal may also result in various diseases. Abrupt cessation leads to a proportional increase in saturated fatty acids and cholesterol at the membrane level, thereby resulting in increased membrane fragility and endothelial damage (6). It may also lead to hallucinations, hypertension, seizures, and agitation, as seen in our patient.

A recent case report by Mengil et al. (5) evaluated a patient with PRES associated with abrupt alcohol withdrawal who had been consuming alcohol for a period of 35 years. In our patient, however, the history of alcohol abuse was less than 1.5 years and the PRES was associated with the consumption of under-thecounter alcohol. Accordingly, available literature indicates that the duration of disease activity in patients with PRES may vary according to the type of alcohol and the duration of alcohol abuse.

In the case presented, alcohol withdrawal symptoms indicated the presence of chronic alcohol abuse and the diagnosis of PRES was supported by the findings of MRI and clinical improvement. These findings suggest that PRES may result from both chronic alcohol abuse and alcohol withdrawal. Finally, the history of alcohol abuse in our patient implies that the consumption of synthetic alcohol may lead to a relatively higher risk of adverse effects and disease development. Accordingly, patients presenting with a history of alcohol abuse should be probed about the type of alcohol and the total duration of alcohol abuse. Additionally, patients should be informed about the toxicity of synthetic alcohol in comparison with fermentation alcohol. 


\section{Ethics}

Informed Consent: The case was presented with the patients approval.

Peer-review: Externally peer-reviewed.

\section{Authorship Contributions}

Surgical and Medical Practices: Y.İ.G., Concept: Y.İ.G., C.Ç., Design: Y.İ.G., C.Ç., Data Collection or Processing: Y.İ.G., C.Ç., Analysis or Interpretation: Y.İ.G., C.Ç., Literature Search: Y.İ.G., C.Ç., Writing: Y.İ.G., C.Ç.

Conflict of Interest: No conflict of interest was declared by the authors.

Financial Disclosure: The authors declared that this study received no financial support.

\section{References}

1. Hinchey J, Chaves C, Appignani B, et al. A reversible posterior leukoencephalopathy syndrome. N Engl J Med 1996;334:494-500.

2. Fittro K, Dizon R. Understanding posterior reversible encephalopathy syndrome. JAAPA 2018;31:31-34.

3. Levitt A, Zampolin R, Burns J, Bello JA, Slasky SE. Posterior reversible encephalopathy syndrome and reversible cerebral vasoconstriction syndrome: distinct clinical entities with overlapping pathophysiology. Radiol Clin North Am 2019;57:1133-1146.

4. Chen Z, Shen GQ, Lerner A, Gao B. Immune system activation in the pathogenesis of posterior reversible encephalopathy syndrome. Brain Res Bull 2017;131:93-99.

5. Mengil T, Seçil Y, Çoban A, Beckmann Y. Posterior reversible encephalopathy syndrome triggerred by alcohol withdrawal. Türk Psikiyatri Derg 2017;28:217-220.

6. Le Daré B, Lagente V, Gicquel T. Ethanol and its metabolites: update on toxicity, benefits, and focus on immunomodulatory effects. Drug Metab Rev 2019;51:545-561. 